\title{
Optimization of Medium Composition and Cultivation Parameters for Fructosyltransferase Production by Penicillium aurantiogriseum AUMC 5605
}

\author{
Mohamed Abdel-Fattah Mohamed Farid* • Zinat Kamel • \\ Elsayed Ahmed Elsayed • Azza Mohamed Noor El-Deen
}

Received: 17 February 2015 / Accepted: 23 April 2015 / Published Online: 30 September 2015

(C) The Korean Society for Applied Biological Chemistry 2015

\begin{abstract}
Fructooligosaccharides have been mainly produced by microbial fructosyltransferases (FTase) enzymes. The present work focuses on the optimization of medium composition and cultivation parameters affecting FTase produced by Penicillium aurantiogriseum AUMC 5605 in shake flask cultivation. FTase production was optimized in two steps using DeMeo's fractional factorial design. A 1.46-fold increase in FTase production (105.4 $\mathrm{U} / \mathrm{mL}$ ) was achieved using the optimized culture medium consisting of $(\mathrm{g} / \mathrm{L})$ : sucrose, 600; yeast extract, $10 ; \mathrm{K}_{2} \mathrm{HPO}_{4}, 5$; $\mathrm{MgSO}_{4} \cdot 7 \mathrm{H}_{2} \mathrm{O}, 0.5 ;\left(\mathrm{NH}_{4}\right)_{2} \mathrm{SO}_{4}, 1.0$ and $\mathrm{KCl}, 0.5$. The obtained results showed that the maximum FTase enzyme activity was produced at initial cultivation $\mathrm{pH}$ values ranging from $6.0-6.5$, at agitation speed of $200 \mathrm{rpm}$ and using vegetative fungal cells as inoculum. Moreover, results showed that optimization of medium composition and some cultivation parameters resulted in an
\end{abstract}

M. A. M. Farid

Natural and Microbial Products Department, National Research Centre, Dokki, Giza, Egypt

Z. Kamel

Faculty of Science, Cairo University, Egypt

\section{E. A. Elsayed}

Natural and Microbial Products Department, National Research Centre, Dokki, Giza, Egypt; Advanced Chair for Proteomics and Cytomics Research, Faculty of Science, King Saud University, 1145 Riyadh, Kingdom of Saudi Arabia

\section{A. M. Noor El-Deen}

Natural and Microbial Products Department, National Research Centre, Dokki, Giza, Egypt

*Corresponding author (M. A. M. Farid: nrcfarid@yahoo.com)

This is an Open Access article distributed under the terms of the Creative Commons Attribution Non-Commercial License (http://creativecommons. org/licenses/by-nc/3.0/) which permits unrestricted non-commercial use, distribution, and reproduction in any medium, provided the original work is properly cited. increase of about $93.7 \%$ in the enzyme activity than the nonoptimized cultivation conditions after $96 \mathrm{~h}$ of cultivation. Additionally, maximum production and specific production rates recorded $2340 \mathrm{U} / \mathrm{L} / \mathrm{h}$ and $102 \mathrm{U} / \mathrm{L} / \mathrm{h} / \mathrm{g}$ cells, respectively.

Keywords DeMeo's fractional factorial design · fructosyltransferases - growth kinetics $\cdot$ medium optimization $\cdot$ Penicillium aurantiogriseum

\section{Introduction}

Microbial fructooligosaccharides (FOS) have attracted special attention and are attributed to the expansion of the sugar market due to mass production is not complicated and the similarity of sweet taste to sucrose, a traditional sweetener. FOS are caloriefree and noncariogenic sweeteners, stimulate the growth of bifidobacteria, and have been claimed to contribute towards the prevention of colon cancer and to reduce cholesterol, phospholipids and triglyceride levels in serum (Yun, 1996). The enzymes catalyzing the production of FOS are classified as fructosyltransferases (FTase, E.C. 2.4.1.9), or $\beta$-fructofuranosidases (FFase, E.C. 3.2.1.26) (Maiorano et al., 2008). FTase catalyzes the transfer of a fructosyl group to a molecule of sucrose or a fructooligosaccharide when a FOS chain which has one fructosyl unit more, is formed. The enzyme shows a little affinity towards water as an acceptor, due to its very low hydrolase activity. The yields of FOS prepared by the action of the FTases were generally high even in dilute substrate solutions (Antošová and Polakoviè, 2001).

A number of fructosyltransferic microorganisms have been reported, including fungi belonging to genera Aspergillus (Aspergillus niger, Aspergillus oryzae, Aspergillus foetidus, Aspergillus phoenicis); Fusarium (Fusarium oxysporum); Penicillium (Penicillium citrinum, Penicillium rugulosum, 
Penicillium purpurogenum) and Aureobasidium (Aureobasidium pullulans) (Sangeetha et al., 2004; Maiorano et al., 2008; Ottoni et al., 2012). Investigations of the effect of the cultivation media composition and cultivation conditions on the FTase production by different strains have been performed by several authors (Vandáková et al., 2004; Lim et al., 2006; Wang and Zhou, 2006). The comparison of the effect of carbon source at the cultivation of different microorganisms showed that sucrose was by far the best inducer of FTase production (Hayashi et al., 1992; Chen and Liu, 1996). Cell growth and enzyme production are also influenced by the nitrogen source. Complex nitrogen sources, such as yeast extract and corn steep liquor, enhance the production of FTase but other nitrogen sources such as urea, $\left(\mathrm{NH}_{4}\right)_{2} \mathrm{SO}_{4}, \mathrm{NaNO}_{3}$ and $\mathrm{NH}_{4} \mathrm{NO}_{3}$ can limit the enzyme production (Balasubramaniem et al., 2001). Similarly, yeast extract was declared to be the best nitrogen source (Hayashi et al., 1992; Chen and Liu, 1996). Another common subject of investigation was the effect of minerals, mainly phosphorus, magnesium, iron, and calcium, on the FTase production and cell growth (Sangeetha et al., 2005; Dhake and Patil, 2007).

However, there is no report on the transfructosylating enzyme activity of Penicillium aurantiogriseum. The aim of this study is to optimize the media components and cultivation parameters affecting the production of FTase by a locally isolated fungus, Penicillium aurantiogriseum AUMC 5605, in shake-flask cultivation.

\section{Materials and Methods}

Microorganism, maintenance and cultivation parameters. A fungal strain was isolated from Egyptian soil sample taken from Alfayoum region and was identified as Penicillium aurantiogriseum AUMC 5605 (Assiut University, Mycological Center, Faculty of Science, Egypt) according to the methods of Moubasher (1993) and Samson et al. (2000). The producing strain was regularly maintained on yeast sucrose agar medium containing $(\mathrm{g} / \mathrm{L})$ : yeast extract, 2; sucrose, 50; agar, 20 and distilled water $1 \mathrm{~L}$. The $\mathrm{pH}$ of the medium was adjusted to 6.5 prior to sterilization.

Inoculum preparation. A vegetative growth medium was used to prepare the inoculums for the enzyme production experiments. This medium contained $(\mathrm{g} / \mathrm{L})$ : Yeast extract, $10 ; \mathrm{K}_{2} \mathrm{HPO}_{4}, 5.0$; $\mathrm{NaNO}_{3}, 10.0 ; \mathrm{MgSO}_{4} \cdot 7 \mathrm{H}_{2} \mathrm{O}, 0.5$ and sucrose 100 ; distilled water $1 \mathrm{~L}$ (Yun et al., 1997). The $\mathrm{pH}$ was adjusted to 6.5 before sterilization. Spores of the producing strain from 6-7 day old agar slants (approximately $1 \times 10^{6} \mathrm{spore} / \mathrm{mL}$ ) were used to inoculate $50 \mathrm{~mL}$ of the vegetative growth medium and then incubated at $28 \pm 2^{\circ} \mathrm{C}$ in an incubator shaker at $200 \mathrm{rpm}$ for 24 hours (approximately $1 \times 10^{4}$ cells $/ \mathrm{mL}$ ). Cells count was measured by the dilution plate count method (Parkinson et al., 1971).

Production medium and batch cultivation. Unless otherwise stated, batch fermentation was conducted in $250 \mathrm{~mL}$ Erlenmeyer flasks containing $50 \mathrm{~mL}$ of production medium (Yun et al., 1997) $(\mathrm{g} / \mathrm{L})$ : sucrose, 200; yeast, $10.0 ; \mathrm{K}_{2} \mathrm{HPO}_{4}, 5.0 ; \mathrm{MgSO}_{4} \cdot 7 \mathrm{H}_{2} \mathrm{O}, 0.5$; $\left(\mathrm{NH}_{4}\right)_{2} \mathrm{SO}_{4}, 1.0 ; \mathrm{KCl}, 0.5$. The $\mathrm{pH}$ of the medium was adjusted to
Table 1 The De Meo's design of experimental runs used for FTase production

\begin{tabular}{cccccccc}
\hline \multirow{2}{*}{ Expr. run } & \multicolumn{7}{c}{ Constituents } \\
\cline { 2 - 8 } & A & B & C & D & E & F & G \\
\hline 1 & L & L & L & H & H & H & L \\
2 & H & L & L & L & L & H & H \\
3 & L & H & L & L & H & L & H \\
4 & H & H & L & H & L & L & L \\
5 & L & L & H & H & L & L & H \\
6 & H & L & H & L & H & L & L \\
7 & L & H & H & L & L & H & L \\
8 & H & H & H & H & H & H & H \\
\hline
\end{tabular}

$\mathrm{H}$, high level value; $\mathrm{L}$, low level value; $\mathrm{A}$, sucrose; $\mathrm{B}$, Yeast extract. $\mathrm{C}, \mathrm{K}_{2} \mathrm{HPO}_{4} ; \mathrm{D}, \mathrm{MgSO}_{4} .7 \mathrm{H}_{2} \mathrm{O} ; \mathrm{E} \mathrm{NaNO}_{3} ; \mathrm{F},\left(\mathrm{NH}_{4}\right)_{2} \mathrm{SO}_{4} ; \mathrm{G}, \mathrm{KCl}$.

6.0 before autoclaving at $121^{\circ} \mathrm{C}$ for $20 \mathrm{~min}$. Sucrose was sterilized separately and added aseptically after cooling the flasks containing the production medium. Unless otherwise stated, vegetative growing cells $(10 \mathrm{~mL})$ of $P$. aurantiogriseum AUMC 5605 of $24 \mathrm{~h}$ old were used to inoculate production medium $(50 \mathrm{~mL}$ in $250 \mathrm{~mL}$ Erlenmeyer flasks). The flasks were then incubated on a rotary shaker at $200 \mathrm{rpm}$ at $28 \pm 2^{\circ} \mathrm{C}$. After $144 \mathrm{~h}$, the cultures were harvested and the necessary analyses were done.

Medium optimization. A fractional factorial experimental design described by De Meo et al. (1985) was used for the optimization of production medium for FTase production in submerged fermentation by $P$. aurantiogriseum AUMC 5605. In the present study, seven different components namely: sucrose (A), yeast extract (B), $\mathrm{K}_{2} \mathrm{HPO}_{4}(\mathrm{C}), \mathrm{MgSO}_{4} \cdot 7 \mathrm{H}_{2} \mathrm{O}$ (D), $\mathrm{NaNO}_{3}(\mathrm{E}),\left(\mathrm{NH}_{4}\right)_{2} \mathrm{SO}_{4}(\mathrm{~F})$, and $\mathrm{KCl}(\mathrm{G})$ were taken into consideration in eight experiments. In Table 1, the rows represent eight different experiments while columns represent different components. For each component, high $(\mathrm{H})$ and low $(\mathrm{L})$ concentrations were tested. For evaluation of the effect of each constituent, the coefficients fructosyltransferase activity $(\mathrm{Cp})$, biomass dry weight $(\mathrm{Cx})$ and specific activity $(\mathrm{Cs})$ were calculated as follows. If $\mathrm{P}$ is the FTase activity $(\mathrm{U} / \mathrm{L}), \mathrm{X}$ is the biomass dry weight $(\mathrm{g} / \mathrm{L})$ and $\mathrm{S}$ is the specific activity of FTase (U/mg proteins), the coefficients $\mathrm{Cp}, \mathrm{Cx}$ and $\mathrm{Cs}$ relating to each of the seven constituents are given by:

$$
\begin{aligned}
& C_{p j}=1 / 8\left[\begin{array}{ll}
\Sigma_{i=1}^{8} & A j \times P_{i}
\end{array}\right] \\
& C_{x j}=1 / 8\left[\begin{array}{ll}
\Sigma_{i=1}^{8} & A j \times X_{i}
\end{array}\right] \\
& C_{s j}=1 / 8\left[\begin{array}{ll}
\Sigma_{i=1}^{8} & A j \times S_{i}
\end{array}\right]
\end{aligned}
$$

Here, $\mathrm{Aj}$ means either $\mathrm{H}$ or $\mathrm{L}$ level in experimental run i. If a calculated coefficient has a positive value, it means that the particular constituent has positive effect at its high level. P refers to FTase activity, $\mathrm{X}$ to biomass dry weight and $\mathrm{S}$ to specific activity of FTase. Media optimization was carried out in two steps. The first step was to determine the effect of each constituent on production of FTase, while the second step was to further adjust the levels of constituents for higher production of the enzyme.

Determination of FTase activity. Fructosyltransferase activity in 
culture filtrate was measured by estimating the liberated reducing sugar released from sucrose as described by Duan et al. (1993) using glucose as a standard. The assay mixture contained appropriately $0.1 \mathrm{~mL}$ of the enzyme solution, ( $0.15 \mathrm{M}$ Mcllvaine buffer $\mathrm{pH} 5.5)$ and $0.4 \mathrm{~mL}$ of $50 \%(\mathrm{~W} / \mathrm{V})$ sucrose solution. The reaction mixture was incubated at $55^{\circ} \mathrm{C}$ for one $\mathrm{h}$. At the end of the incubation time, the reaction was stopped by adding copper reagent. The amount of reducing sugar liberated was determined spectrophotometrically at $520 \mathrm{~nm}$ using glucose as a standard according to Somogyi (1945). One unit of the enzyme activity was defined as the amount that produced $1 \mu \mathrm{mol}$ of reduced sugar per minute under the above assay conditions.

Determination of extracellular protein. The protein content of the crude enzyme source was determined by the method of Lowry et al. (1951) using bovine serum albumin as a standard.

Determination of cell dry weight. The cell dry weight (CDW) was determined by harvesting the fungal mycelia through filtration using Whatman paper No. 1, washed twice with distilled water and dried overnight at $70^{\circ} \mathrm{C}$ in an oven and weighed until a constant dry weight was obtained.

Data analysis. Treatment effects were analyzed and the mean comparison was performed by ANOVA One-Way analysis of variance using computer software Minitab 16 and the average values were reported. Significant differences among the replicates have been presented at the $95 \%$ confidence level $(p \leq 0.05)$.

\section{Results and Discussion}

In batch fermentation, $P$. aurantiogriseum AUMC 5605 grow in the production medium (Yun et al., 1997) with initial $\mathrm{pH} 6.0$ at $30^{\circ} \mathrm{C}$ for $144 \mathrm{~h}$ and $200 \mathrm{rpm}$ produced a maximum activity of about $72 \mathrm{U} / \mathrm{mL}$.

De Meo's fractional factorial design is a valuable tool for rapid evaluation of the effects of different media constituents. This design is a preliminary technique, which tests only two levels of each medium component, but cannot determine the exact quantity of each constituent required for best performance in the medium. However, the method suggests the importance of each constituent. This design is as efficient as that of Placket-Burman design for fermentation media optimization for production of aroma, nuclease P1 and $\beta$-fructofuranosidase (Ashokkumar et al., 2001).

First optimization step. The different levels of constituents used in first optimization step are given in Table 2. FTase activity, specific activity and enzyme yield from the fermentation trails are given in Table 3. The calculated coefficient values for FTase activity $\left(\mathrm{C}_{\mathrm{p}}\right)$, biomass dry weight $\left(\mathrm{C}_{\mathrm{x}}\right)$ and specific activity $\left(\mathrm{C}_{\mathrm{s})}\right.$ are also shown in Table 4 . In all the eight runs, FTase activity varied from 70.26 to $101 \mathrm{U} / \mathrm{mL}$ with a mean of $86.7 \mathrm{U} / \mathrm{mL}$ while its specific activity ranged between 9.7 and $13.7 \mathrm{U} / \mathrm{mg}$ proteins with a mean of about $11.4 \mathrm{U} / \mathrm{mg}$ proteins. Similarly, there were wide variations in the amount of the soluble protein $(7.2-9.7 \mathrm{mg} / \mathrm{mL})$ and biomass yield (27.9-42.5 g/L) from the different fermentation trials. In the first step, constituents such as sucrose, yeast extract
Table 2 Different levels of constituents used in first and second optimization steps

\begin{tabular}{lcccc}
\hline \multirow{2}{*}{ Components } & \multicolumn{2}{c}{ First step } & \multicolumn{2}{c}{ Second step } \\
\cline { 2 - 5 } & $\begin{array}{c}\text { Low level } \\
\left(\mathrm{g} \mathrm{L}^{-1}\right)\end{array}$ & $\begin{array}{c}\text { High level } \\
\left(\mathrm{g} \mathrm{L}^{-1}\right)\end{array}$ & $\begin{array}{c}\text { Low level } \\
\left(\mathrm{g} \mathrm{L}^{-1}\right)\end{array}$ & $\begin{array}{c}\text { High level } \\
\left(\mathrm{g} \mathrm{L}^{-1}\right)\end{array}$ \\
\hline Sucrose & 200 & 600 & 400 & 600 \\
Yeast extract & 5 & 10 & 5 & 10 \\
$\mathrm{~K}_{2} \mathrm{HPO}_{4}$ & 2 & 5 & 1 & 2 \\
$\mathrm{MgSO}_{4} \cdot 7 \mathrm{H}_{2} \mathrm{O}$ & 0.5 & 1 & 0.2 & 0.5 \\
$\mathrm{NaNO}_{3}$ & 5 & 10 & 2 & 6 \\
$\left(\mathrm{NH}_{4}\right)_{2} \mathrm{SO}_{4}$ & 2 & 10 & 0.2 & 1 \\
$\mathrm{KCl}$ & 0.1 & 2 & 0.1 & 0.5 \\
\hline
\end{tabular}

Table 3 FTase activity, specific activity and yield for first and second optimization steps

\begin{tabular}{|c|c|c|c|}
\hline \multirow[b]{2}{*}{ Run } & \multicolumn{3}{|c|}{ First step } \\
\hline & $\begin{array}{c}\text { FTase activity } \\
\left(\mathrm{U} \mathrm{mL}^{-1}\right)\end{array}$ & $\begin{array}{l}\text { Specific Activity } \\
\text { (U mg }{ }^{-1} \text { protein) }\end{array}$ & $\begin{array}{c}\text { Yield } \\
\left(\mathrm{U} \mathrm{g} \mathrm{cells}^{-1}\right)\end{array}$ \\
\hline 1 & $70.26 \pm 3.04^{\mathrm{d}}$ & $9.77 \pm 1.85$ & $1824.14 \pm 113.08$ \\
\hline 2 & $94.81 \pm 3.98^{\mathrm{ab}}$ & $9.75 \pm 0.69$ & $2960.85 \pm 337.05$ \\
\hline 3 & $76.56 \pm 0.16^{\mathrm{cd}}$ & $10.55 \pm 0.25$ & $1989.53 \pm 16.55$ \\
\hline 4 & $96.27 \pm 1.59^{\mathrm{ab}}$ & $12.25 \pm 0.94$ & $3449.43 \pm 101.93$ \\
\hline 5 & $74.09 \pm 0.48^{\mathrm{cd}}$ & $9.98 \pm 0.51$ & $1743.19 \pm 40.25$ \\
\hline 6 & $101.00 \pm 1.27^{\mathrm{a}}$ & $11.53 \pm 0.66$ & $3101.20 \pm 100.49$ \\
\hline 7 & $85.35 \pm 5.89 b^{c}$ & $13.71 \pm 1.74$ & $2157.29 \pm 190.47$ \\
\hline \multirow[t]{3}{*}{8} & $95.48 \pm 2.07^{\mathrm{ab}}$ & $13.21 \pm 0.89$ & $2624.28 \pm 119.77$ \\
\hline & \multicolumn{3}{|c|}{ Second step } \\
\hline & $\begin{array}{l}\text { FTase activity } \\
\left(\mathrm{U} \mathrm{mL}^{-1}\right)\end{array}$ & $\begin{array}{l}\text { Specific Activity } \\
\text { (U mg }{ }^{-1} \text { protein) }\end{array}$ & $\begin{array}{c}\text { Yield } \\
\left(\mathrm{U} \text { g cells }{ }^{-1}\right)\end{array}$ \\
\hline 1 & $90.53 \pm 7.49^{\mathrm{b}}$ & $12.88 \pm 1.50$ & $2149.88 \pm 295.75$ \\
\hline 2 & $103.14 \pm 1.11^{\mathrm{ab}}$ & $22.44 \pm 0.24$ & $2855.47 \pm 129.33$ \\
\hline 3 & $93.12 \pm 0.0^{\mathrm{ab}}$ & $12.60 \pm 0.0$ & $2300.89 \pm 94.15$ \\
\hline 4 & $103.36 \pm 0.48^{\mathrm{a}}$ & $11.13 \pm 1.36$ & $2550.96 \pm 77.29$ \\
\hline 5 & $93.79 \pm 2.23^{\mathrm{ab}}$ & $15.91 \pm 2.56$ & $2434.91 \pm 51.23$ \\
\hline 6 & $103.25 \pm 1.27^{\mathrm{ab}}$ & $11.97 \pm 1.66$ & $2633.58 \pm 156.74$ \\
\hline 7 & $96.83 \pm 4.30^{\mathrm{ab}}$ & $20.34 \pm 0.30$ & $2621.37 \pm 18.07$ \\
\hline 8 & $105.39 \pm 0.80^{\mathrm{a}}$ & $22.61 \pm 2.00$ & $3060.25 \pm 338.75$ \\
\hline
\end{tabular}

Means followed by different letters within each column differ significantly at $p \leq 0.05 ; \pm$ indicates standard deviation among replicates.

and $\mathrm{K}_{2} \mathrm{HPO}_{4}$ showed positive coefficients for FTase activity whereas $\mathrm{MgSO}_{4} \cdot 7 \mathrm{H}_{2} \mathrm{O}, \mathrm{NaNO}_{3},\left(\mathrm{NH}_{4}\right)_{2} \mathrm{SO}_{4}$ and $\mathrm{KCl}$ showed negative coefficients (Table 4). However, all constituents except $\mathrm{MgSO}_{4}$, $\mathrm{NaNO}_{3}$ and $\mathrm{KCl}$ showed positive coefficients for specific activity. On the other hand, all constituents except sucrose, yeast extract and $\left(\mathrm{NH}_{4}\right)_{2} \mathrm{SO}_{4}$ had positive coefficients on the growth and cell biomass production.

Second optimization step. In the second optimization step, the levels of the constituents were adjusted based on the results of the first optimization step. As sodium nitrate, $\left(\mathrm{NH}_{4}\right)_{2} \mathrm{SO}_{4}, \mathrm{KCl}$, and $\mathrm{MgSO}_{4} \cdot 7 \mathrm{H}_{2} \mathrm{O}$ exhibited negative effects on both FTase activity and its specific activity in the first step of media optimization, their levels were reduced to levels below to their low levels. 
Table 4 Coefficient for FTase activity $(C p)$ and specific activity $(C s)$ and cell dry weight $(C x)$ for each constituent

\begin{tabular}{|c|c|c|c|c|c|c|c|}
\hline \multirow{2}{*}{ Coefficient } & \multicolumn{7}{|c|}{ Medium components } \\
\hline & Sucrose & Yeast extract & $\mathrm{K}_{2} \mathrm{HPO}_{4}$ & $\mathrm{MgSO}_{4}$ & $\mathrm{NaNO}_{3}$ & $\left(\mathrm{NH}_{4}\right)_{2} \mathrm{SO}_{4}$ & $\mathrm{KCl}$ \\
\hline & \multicolumn{7}{|c|}{ First optimization step } \\
\hline$C_{p}$ & 10.16 & 1.69 & 2.25 & -2.7 & -0.9 & -21.59 & -1.49 \\
\hline$C_{s}$ & 0.34 & 1.09 & 0.76 & -0.04 & -0.08 & -3.16 & -0.47 \\
\hline \multirow[t]{2}{*}{$C_{x}$} & -3.77 & -0.41 & 1.76 & 0.33 & 0.49 & -9.26 & 1.35 \\
\hline & \multicolumn{7}{|c|}{ Second optimization step } \\
\hline$C_{p}$ & 5.11 & 1 & 1.14 & -0.41 & -0.61 & -23.91 & 0.18 \\
\hline$C_{s}$ & 0.8 & 0.43 & 1.47 & -0.6 & -1.22 & -1.75 & 2.16 \\
\hline$C_{x}$ & -0.97 & -0.45 & -1.26 & 0.36 & 0.52 & -10.37 & -1.15 \\
\hline
\end{tabular}

Similarly, the concentration of $\mathrm{K}_{2} \mathrm{HPO}_{4}$ was also decreased whereas; the low level of sucrose was raised to $400 \mathrm{~g} / \mathrm{L}$. The level of yeast extract was set at its concentration of the first step science yeast extract contains abundant nitrogen compounds as well as many growth factors its addition can stimulate FTase production by $P$. aurantiogriseum AUMC 5605. The optimal concentration of yeast extract for FFase production was between 1.5 to 3\% (W/V) (Hayashi et al., 1992; Chen, 1995). The concentration of each constituent for the second optimization step is shown in Table (2). In all eight runs (Table 3 ), the FTase activity varied from 90.5 to $105.4 \mathrm{U} / \mathrm{mL}$ with a mean of $98.7 \mathrm{U} / \mathrm{mL}$ which is higher than the mean of FTase activity in the first step $(86.7 \mathrm{U} / \mathrm{mL})$ representing about 1.14-fold higher than in the first step. The maximum FTase activity in the eighth run of second step was 1.46-fold higher than that of enzyme activity before optimization $(72.2 \mathrm{U} / \mathrm{mL})$. Similarly the specific activity of FTase in the second optimization step varied from 11.1 to $22.6 \mathrm{U} / \mathrm{mg}$ protein and its mean value (16.24 $\mathrm{U} / \mathrm{mg}$ ) higher than that of the first step $(11.4 \mathrm{U} / \mathrm{mg})$. The calculated coefficient values for the second step suggested that $\mathrm{MgSO}_{4}$ and $\mathrm{NaNO}_{3}$, showing again a negative effect for both FTase and its specific activity, while the other constituents exhibited positive effect on both factors (Table 4). Therefore, sodium nitrate was omitted and low level of $\mathrm{MgSO}_{4}$ in the second optimization step was taken in designing optimized medium.

Fructosyltransferase production is significantly influenced by carbon source. Sucrose was the best carbon source to FTase production and growth although Wang and Rakshit (1999) showed that maltose at $10 \mathrm{~g} / \mathrm{L}(\mathrm{W} / \mathrm{V})$ was the best carbon source for transferase enzyme production by $A$. foetidus NRRL 337. Chen and Liu (1996) reported that the optimal enzyme production was achieved with $250 \mathrm{~g} / \mathrm{L}(\mathrm{W} / \mathrm{V})$ sucrose but maximum cell growth occurred at $100 \mathrm{~g} / \mathrm{L}(\mathrm{W} / \mathrm{V})$ sucrose. The authors suggested that below $100 \mathrm{~g} / \mathrm{L}(\mathrm{W} / \mathrm{V})$ sucrose the large portion of the carbon source was used for cell growth, while high sucrose concentrations resulted in higher enzyme induction but cell growth inhibition. In this work, it is observed that no suppression of FTase production by increasing sucrose concentration (400-600 g/L W/V) was detected, which is contrary to the results of Hayashi et al. (2000). The authors found the largest amount of FTase produced at 100$200 \mathrm{~g} / \mathrm{L}$ (W/V) of sucrose by Aureobasidium pullulans CCY 271-1194 did not show this tendency. The amount of biomass of
Aureobasidium pullulans obtained after 4 days of cultivation was almost the same, 14-16 g/L (W/V), with sucrose ranging from 50 to $350 \mathrm{~g} / \mathrm{L}$. The highest FTase activity was achieved with sucrose at $350 \mathrm{~g} / \mathrm{L}(\mathrm{W} / \mathrm{V})$ and the ratio of intracellular and extracellular activities was independent of sucrose amounts (Antošová et al., 2002). The optimal sucrose concentration for the FTase production shows a large variation for $A$. japonicas and $A$. niger. High FTase production by $A$. japonicus MU-2 (Antošová et al., 2002) and by A. japonicus JN19 (Wang and Zhou, 2006) was reached at 200 and $150-180 \mathrm{~g} / \mathrm{L}(\mathrm{W} / \mathrm{V})$ sucrose, respectively. Differently, FTase production by A. japonicus FCL 119T (Dorta et al., 2006) and by A. niger ATCC 20611 (Cruz et al., 1998) was higher at 30 and 25 $\mathrm{g} / \mathrm{L}(\mathrm{W} / \mathrm{V})$ sucrose, respectively. A low sucrose concentration, from 10 to $100 \mathrm{~g} / \mathrm{L}(\mathrm{W} / \mathrm{V})$, has been employed by several authors for transfructosylation enzyme production (Cuervo et al., 2004; Nguyen et al., 2005; Sangeetha et al., 2005).

The effects of inorganic salts are also reported by various authors. $\mathrm{K}_{2} \mathrm{HPO}_{4}$ is described as a microelement source for cell growth, as well as a buffering reagent. Its optimal concentration ranges from $4 \mathrm{~g} / \mathrm{L}$ (W/V) (Sangeetha et al., 2005) to $5 \mathrm{~g} / \mathrm{L}$ (W/V) (Vandáková et al., 2004; Lim et al., 2006), $\mathrm{Mg}^{2+}$ affects the permeability of the cell wall for A. pullulans (Vandáková et al., 2004) and its optimal concentration varies from $0.3 \mathrm{~g} / \mathrm{L}(\mathrm{W} / \mathrm{V})$ (Sangeetha et al., 2005) to $2 \mathrm{~g} / \mathrm{L}(\mathrm{W} / \mathrm{V})$ (Balasubramaniem et al., 2001). $\mathrm{NaNO}_{3}$ is the most common source of inorganic nitrogen in FTase production by some fungi and can be employed from $2 \mathrm{~g} / \mathrm{L}$ (W/V) (Lim et al., 2006) to $25 \mathrm{~g} / \mathrm{L}$ (W/V) (Dhake and Patil, 2007). The highest FTase production by Aureobasidium pululans was achieved using a culture medium containing (g/L): $\mathrm{K}_{2} \mathrm{HPO}_{4}, 5 ; \mathrm{NaNO}_{3}, 10$ and $\mathrm{MgSO}_{4} \cdot 7 \mathrm{H}_{2} \mathrm{O}, 0.5$ (Vandáková et al., 2004). Those authors noted an increase in the release of FTase into the medium when $\mathrm{MgSO}_{4} \cdot 7 \mathrm{H}_{2} \mathrm{O}$ and $\mathrm{K}_{2} \mathrm{HPO}_{4}$ contents were decreased in the medium. On the other hand, high FTase production and growth stimulation in A. japonicus $\mathrm{JN} 19$ was observed after $\mathrm{MgSO}_{4}$ and $\mathrm{K}_{2} \mathrm{HPO}_{4}$ addition (Wang and Zhou, 2006). Previous workers have not noticed such effects for $A$. japonicus TIT 90076. It has been reported that addition of adequate amounts of $\mathrm{MgSO}_{4}$ and $\mathrm{K}_{2} \mathrm{HPO}_{4}$ in the culture medium would have appositive effect on enzyme production. However, sodium nitrate was found to have no influence on fructofuranosidase (FFase) production from $A$. japonicus TIT 90076 (Chen, 1995). 

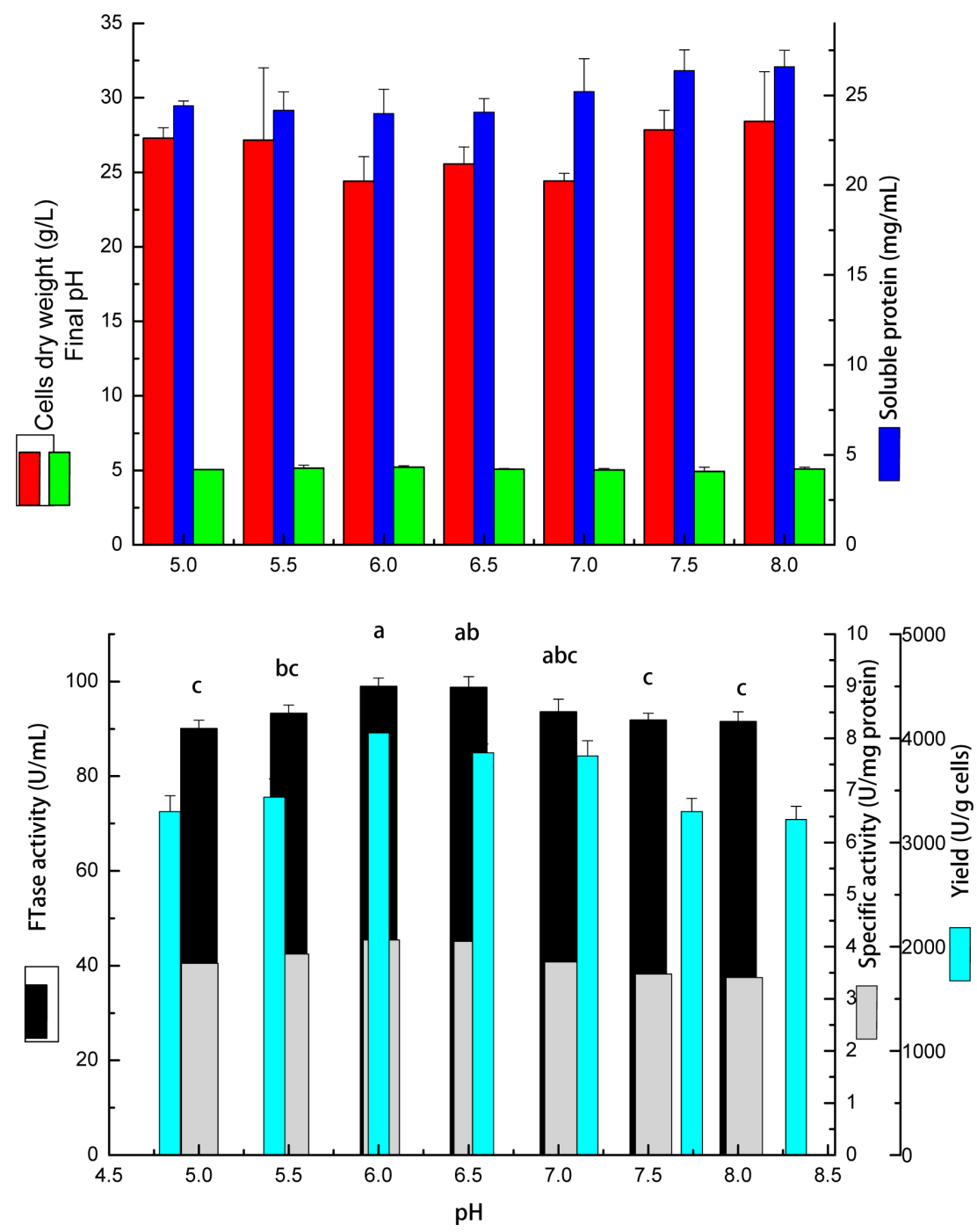

Fig. 1 Effect of initial medium pH on cell growth and FTase production by P. aurantiogriseum AUMC 5605 in a shake-flask system. Y-error bars indicate the standard deviation $( \pm \mathrm{SD})$ among the replicates. Means followed by different letters within FTase activity column differ significantly at $p \leq 0.05$.

Based on the results obtained in the second optimization step, composition of the optimized medium for production of FTase by P. aurantiogriseum AUMC 5605 was formulated to contain $(\mathrm{g} / \mathrm{L})$ : sucrose, 600; yeast extract, $10 ; \mathrm{K}_{2} \mathrm{HPO}_{4}, 5 ; \mathrm{MgSO}_{4} \cdot 7 \mathrm{H}_{2} \mathrm{O}, 0.5$; $\left(\mathrm{NH}_{4}\right)_{2} \mathrm{SO}_{4}, 1.0$ and $\mathrm{KCl}, 0.5$.

Effect of initial $\mathbf{p H}$ value on the production of FTase. Results presented in Fig. 1 show that initial $\mathrm{pH}$ of the fermentation medium was an important factor for the production of fructosyltransferase enzyme. Maximum enzyme level (about $100 \mathrm{U} / \mathrm{mL}$ was obtained when the fungal strain was grown on the fermentation medium initially adjusted within the range of 6.0 to 6.5 . This was correlated with maximum specific activity $(4.1 \mathrm{U} / \mathrm{mg})$ and yield coefficient of about 4054.5 and $3862.5 \mathrm{U} / \mathrm{g}$ cells/L, respectively. A notable decrease in the enzyme activity was observed upon using media initially adjusted to $\mathrm{pH}$ values higher or lower than the suitable range. However, the final $\mathrm{pH}$ values of all fermentation media ranged between $\mathrm{pH} 5.0$ to 5.2. Concerning the cell dry mass, it was observed at $\mathrm{pH} 6-7$ the cells dry mass was almost constant. At lower or higher initial $\mathrm{pH}$ values a noticeable increase of the cell dry mass was recorded. The amount of soluble protein in the fermentation medium increased with the increase of the initial $\mathrm{pH}$ value. For higher FTase production in flasks by $P$. purpurogenum (Chen, 1995), Aspergillus oryzae CFR202 (Sangeetha et al., 2005) and by A. japonicus JN19 (Wang and Zhou, 2006) the best initial $\mathrm{pH}$ found was 5.5. The $\mathrm{pH}$ effect on FTase production in bioreactor by $A$. foetidus NRRL 337 was also studied (Wang and Rakshit, 1999). The $\mathrm{pH}$ was controlled at 4.0, 5.0 and 6.0 and for comparison an uncontrolled $\mathrm{pH}$ condition with initial $\mathrm{pH}$ of 6.0 was run. The results indicated that uncontrolled $\mathrm{pH}$ fermentation produced the highest transferase activity.

Effect of aeration on the production of FTase. Microorganisms vary in their oxygen requirements. In particular, oxygen acts as a terminal electron acceptor for oxidative reactions to provide energy for cellular activities. The variation in the agitation speed 

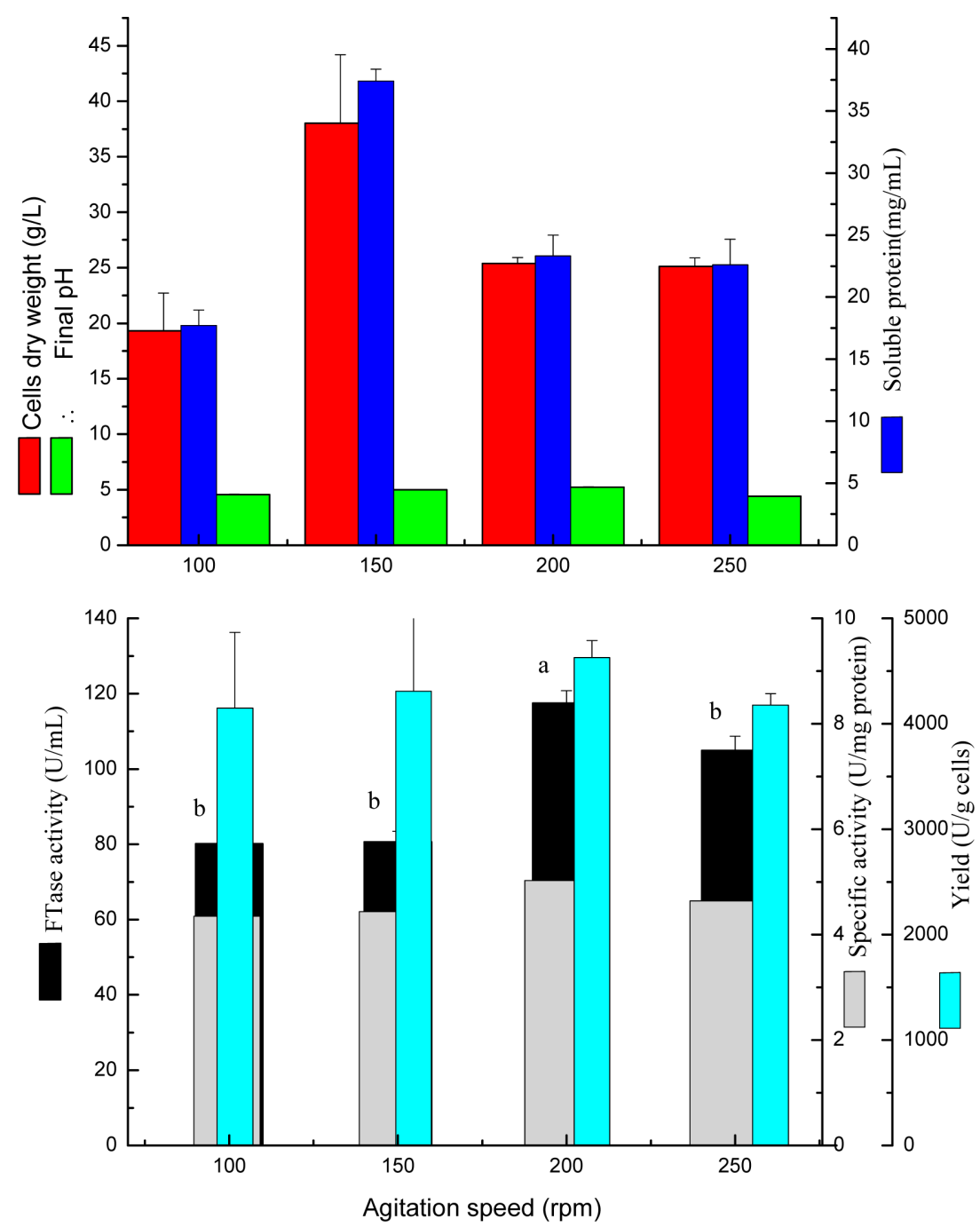

Fig. 2 Effect of agitation speed (rpm) on cell growth and FTase production by P. aurantiogriseum AUMC 5605 in a shake-flask system. Y-error bars indicate the standard deviation $( \pm \mathrm{SD})$ among the replicates. Means followed by different letters within FTase activity column differ significantly at $p \leq 0.05$.

has been found to influence the extent of mixing in the shake flasks or the bioreactor, and also affect the nutrient availability (Nascimento and Martins, 2004).

The effect of aeration was studied through investigating different agitation speeds and different volumes of cultivation medium (Fig. 2). The relation between cell growth, enzyme production as a function of different agitation speeds $(100,150,200$, and 250 $\mathrm{rpm}$ ) revealed that increasing the agitation speed increases cell dry weight, soluble protein and FTase production. It was noticed that at agitation speed of $200 \mathrm{rpm}$ maximum enzyme production $(117.5 \mathrm{U} / \mathrm{mL})$, cell dry weight $(25.38 \mathrm{~g} / \mathrm{L})$ and soluble protein $(23.3 \mathrm{mg} / \mathrm{mL}$ ) were obtained (Fig. 2). It is seen that there is no obvious difference in cell dry weight and soluble protein when the fermentation process was carried out at 200 and $250 \mathrm{rpm}$. It is clear that higher shaking speed resulted in higher enzyme activity. These results may be attributed to the fact that increasing the agitation speed from 100 to $200 \mathrm{rpm}$ tend to increase the amount of dissolved oxygen available to the culture (Bartholomew et al., 1950; Venkatadri and Irvine, 1990). But the increase of enzyme activity slows down from 117.47 to $104.94 \mathrm{U} / \mathrm{mL}$ when shake speed was higher than $200 \mathrm{rpm}$. The low enzyme activities observed at 100 and $150 \mathrm{rpm}$ are most probably caused by poor oxygenation, despite the control of the dissolved oxygen concentration, especially at higher sucrose concentration $(600 \mathrm{~g} / \mathrm{L})$ and also may be due to the inadequate mixing of the broth towards the later stages of growth affected the enzyme synthesis. When the culture medium was subjected to agitation, $P$. purpurogenum failed to grow and there was little fructosyltransferase production (Dhake and Patil, 2007). Agitation has been shown to influence enzyme production in many organisms. Agitation of medium was found to be effective for fructosyltransferase production by $A$. pullulans (Yun et al., 1997). Investigation the relationship between the morphology and rheology properties of $P$. citrinum to improve neo-fructosyltransferase in a $2.5 \mathrm{~L}$ bioreactor was also studied 

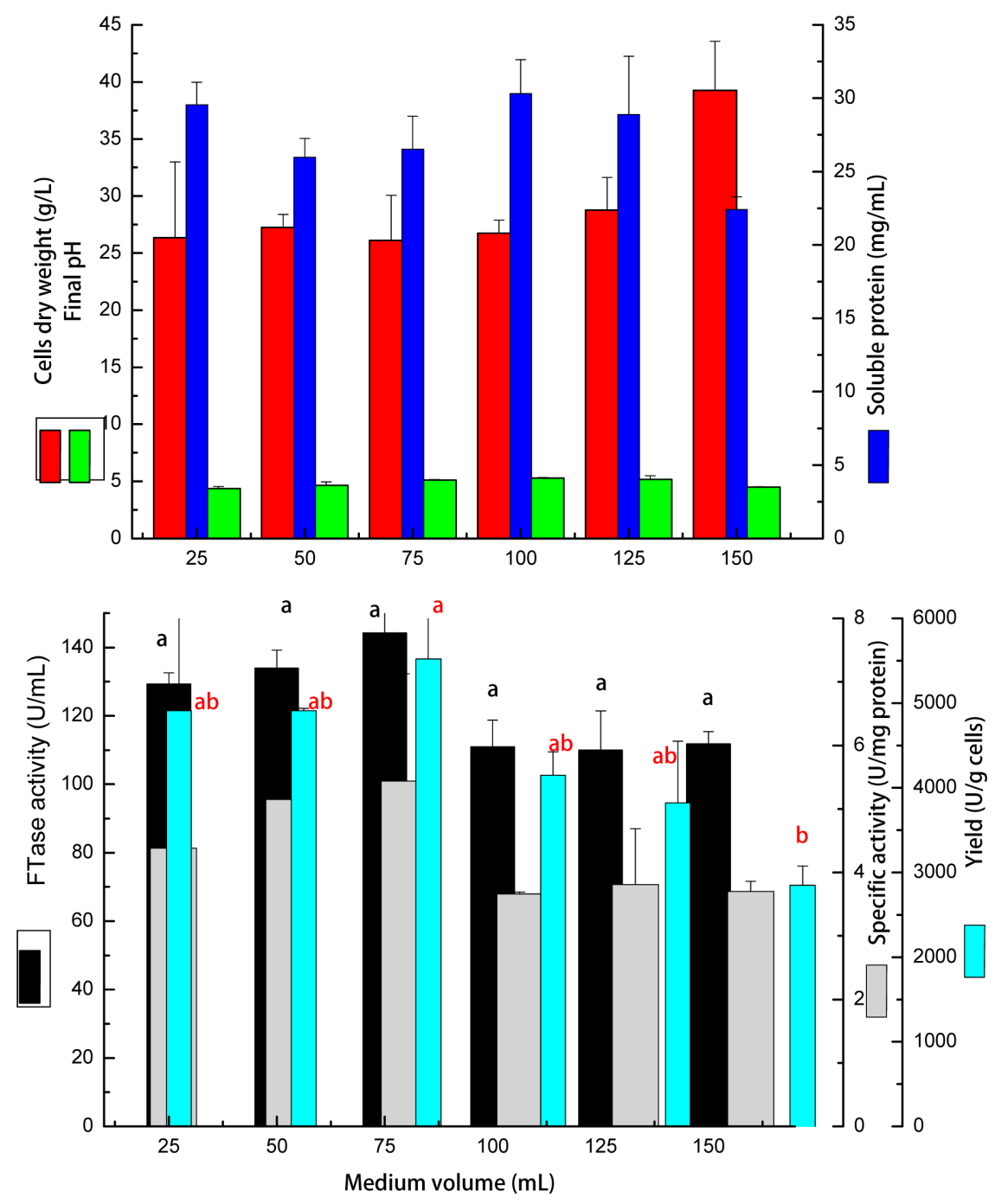

Fig. 3 Effect of different medium volumes on cell growth and FTase production by P. aurantiogriseum AUMC 5605 in a shake-flask system. Y-error bars indicate the standard deviation $( \pm \mathrm{SD})$ among the replicates. Means followed by different letters within FTase activity and yield column differ significantly at $p \leq 0.05$.

(Lim et al., 2006). They mentioned that pellets formation varied during fermentation process due to fermentation parameters (such as nutritional effect, mechanical agitation and aeration effect), lost their rigidity and broke up. These changes in pellet morphology might facilitate enzyme secretion. On the other hand, oxygen dependence at the lower agitation rate varied with the substrate type and its concentration (Lejeune and Baron, 1995). In much fungal fermentation, the high apparent viscosities and the nonNewtonian behavior of the broths necessitate the use of high agitation speeds to provide adequate mixing and oxygen transfer (Amanullah et al., 1999). However, mycelia damage at higher stirring speeds can limit the acceptable range of speeds. The results in Fig. 3 also demonstrate that upon increasing medium volumes, from 25 to $150 \mathrm{~mL} /$ flask, the FTase activity gradually increased and reached its maximal values of $144.2 \mathrm{U} / \mathrm{mL}$ in case of $75 \mathrm{~mL}$ medium volume. Also, results showed that cultivation volume more than $75 \mathrm{~mL} /$ flask has a negative effect on the production of FTase. However, the cell dry weight and the soluble protein increased with increasing medium volume.

Effect of inoculum type and size on the production of FTase. The finite volume of a culture medium means that it can only contain limited nutrients for the micro-organism. Furthermore, the consumption of the nutrients is largely dependent on the population and type of microorganism. To ensure a high production of enzyme in the limited volume of medium, the microorganism inoculum size should therefore be controlled.

The present experiment was undertaken to investigate the effect of inoculum type and size on the production of FTase from $P$. aurantiogriseum AUMC 5605. Different volumes of the prepared vegetative cell inoculums $(5,10,15,20$, and $25 \mathrm{~mL})$, prepared as mentioned in materials and methods, were transferred to the optimized medium of final volume of $50 \mathrm{~mL} /$ flask (inoculum+ fermentation medium) with initial $\mathrm{pH}$ of 6.5 and incubated at $30^{\circ} \mathrm{C}$ on a rotary shaker at $200 \mathrm{rpm}$ for $144 \mathrm{~h}$. Another sets of the 

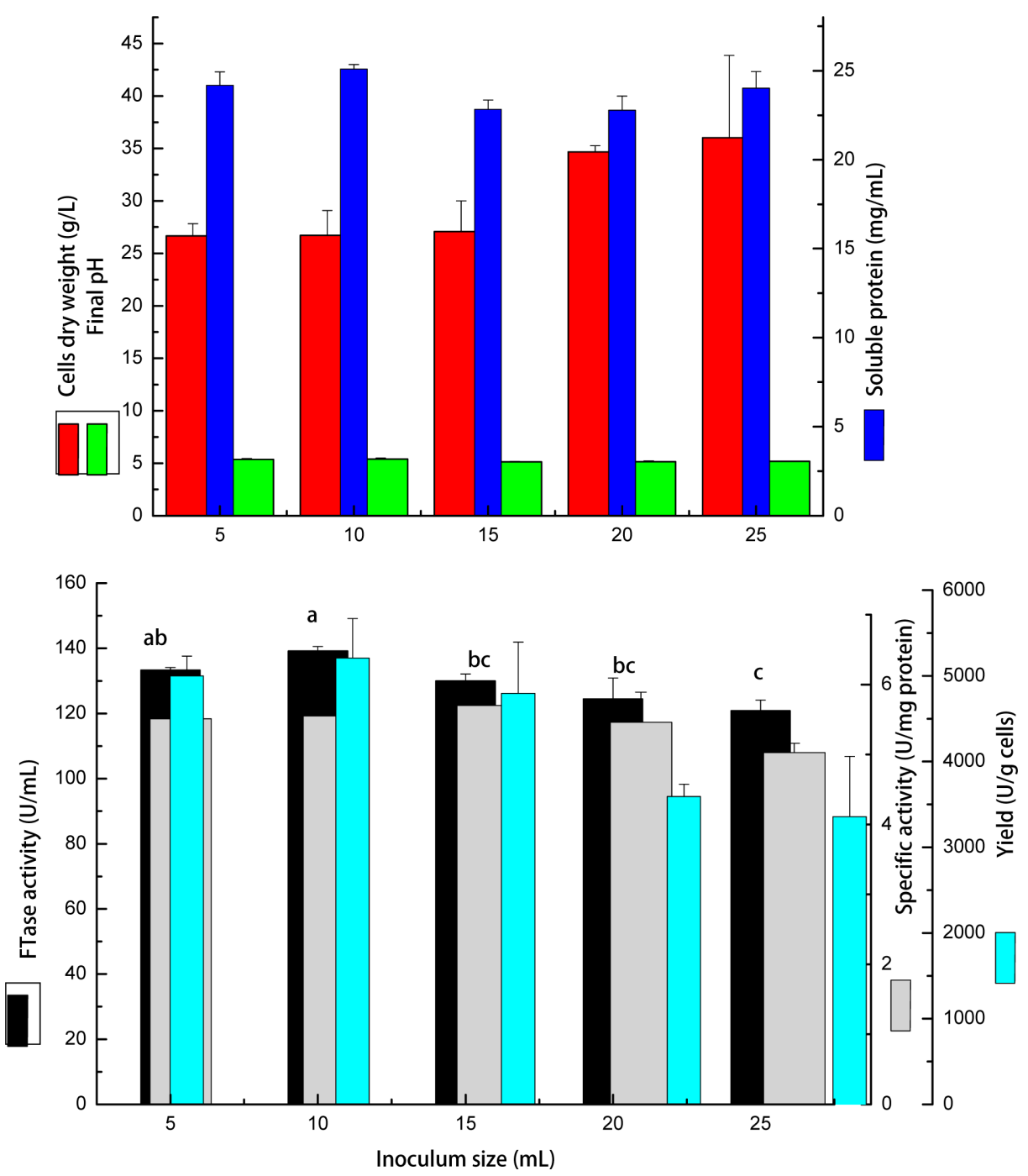

Fig. 4 Effect of different inoculum sizes on cell growth and FTase production by P. aurantiogriseum AUMC 5605 in a shake-flask system. Y-error bars indicate the standard deviation $( \pm \mathrm{SD})$ among the replicates. Means followed by different letters within FTase activity column differ significantly at $p \leq 0.05$.

fermentation medium each containing $50 \mathrm{~mL} /$ flask were inoculated with a spore suspension of one slant of 5 days old and then incubated as previously described. The obtained results (Fig. 4) reveal that highest FTase level was obtained when the culture was inoculated with vegetative cells $(10 \mathrm{~mL} / 50 \mathrm{~mL}$ culture $)$ of $24 \mathrm{~h}$ old. Furthermore, the results showed that increasing the inoculums size more than $10 \mathrm{~mL} / 50 \mathrm{~mL}$ culture, resulted in a gradual decrease in the enzyme level. However, it was noticed that increasing the inoculum size from $15-25 \mathrm{~mL} / 50 \mathrm{~mL}$ culture was accompanied with increase in cell dry mass. Therefore, high inoculum sizes do not necessarily give higher FTase yield. The increase in the production of FTase using small inoculum sizes was suggested to be due to the higher surface area to volume ratio, which resulted in the increased production of FTase. In addition, an improved distribution of dissolve oxygen and more effective uptake of nutrient also contributed to a higher FTase production. If the inoculum sizes are too small, insufficient number of fungi would then lead to a reduced amount of secreted FTase (Frost and Moss, 1987). On the other hand, inoculation with spore suspension of 57 days old results in a lower FTase level.

Growth curve kinetics for the production of FTase by $P$. aurantiogriseum AUMC 5605. Based on the data from previous results, the growth kinetics of batch cultivation were investigated. The results illustrated in Fig. 4 show that the cell growth, soluble protein and enzyme activity of FTase were influenced by the fermentation time. The fungus grew well during the fermentation time and both mycelia growth and protein content increased with the increase of fermentation time. As shown, there was no lag phase observed because the inoculum was in the form of an activated cell mass previously grown for $24 \mathrm{~h}$ in vegetative growth medium. The fungal cell dry weight increased exponentially from about $17 \mathrm{~g} / \mathrm{L}$ at $24 \mathrm{~h}$ to reach its maximum value of $36.1 \mathrm{~g} / \mathrm{L}$ after $168 \mathrm{~h}$. However, the volumetric FTase production increased exponentially from 24 to $96 \mathrm{~h}$ where it reached a maximal value 


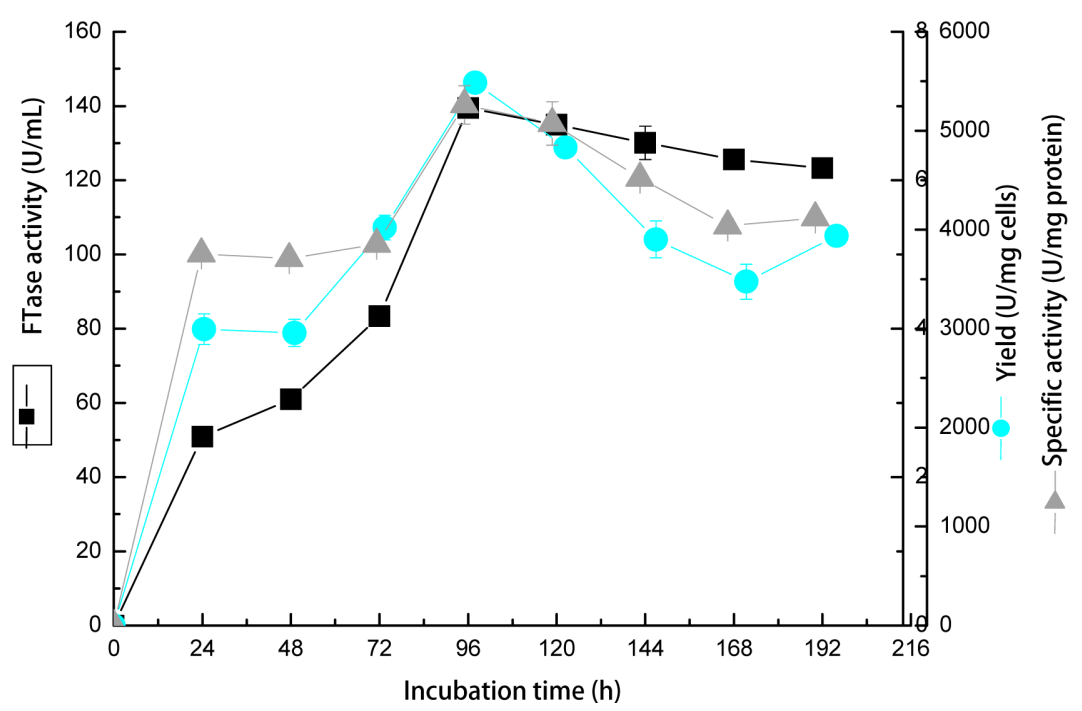

Fig. 5 Growth curve parameters for FTase production of Penicillium aurantiogriseum AUMC 5605 at different time intervals in a shake-flask system. Y-error bars indicate the standard deviation $( \pm \mathrm{SD})$ among the replicates.

of $139.5 \mathrm{U} / \mathrm{mL}$ (about $36.5 \%$ higher than the value of volumetric FTase produced in the batch culture before optimization). After that, the activity remained more or less constant for another $72 \mathrm{~h}$, and began to decrease to reach a minimum value of $123.2 \mathrm{U} / \mathrm{mL}$ after $192 \mathrm{~h}$. The maximal specific enzyme activity and maximal yield coefficient were recorded at $96 \mathrm{~h}$, where they reached 7.01 $\mathrm{U} / \mathrm{mg}$ and $5483.2 \mathrm{U} / \mathrm{g}$ cells/L, respectively. Results in Fig. 5 showed that during the whole cultivation process, the cells grew with a growth rate ranging from 0.1 to $0.23 \mathrm{~g}$ cells/L/h until 168 $\mathrm{h}$, then the cell growth was stopped and at $192 \mathrm{~h}$ they started to die with a death rate of $-0.2 \mathrm{~g}$ cells $/ \mathrm{L} / \mathrm{h}$. Concerning the production and specific production rates, both rates increased gradually with time, till reaching their maximal values at $96 \mathrm{~h}(2340 \mathrm{U} / \mathrm{L} / \mathrm{h}$ and $102 \mathrm{U} / \mathrm{L} / \mathrm{h} / \mathrm{g}$ cells, respectively). Then, both rates were sharply decreased recording $-187.7 \mathrm{U} / \mathrm{L} / \mathrm{h}$ and $-7.05 \mathrm{U} / \mathrm{L} / \mathrm{h} / \mathrm{g}$ cells at $120 \mathrm{~h}$, respectively. Thereafter, the produced enzyme was degraded with a degradation rate ranging from -96.1 to $-202.7 \mathrm{U} / \mathrm{L} / \mathrm{h}$.

Acknowledgment This study was supported by the academic research fund of National Research Centre, Dokki, Giza, Egypt.

\section{References}

Amanullah A, Blair R, Nienow AW, and Thomas CR (1999) Effect of agitation intensity on mycelial morphology and protein production in chemostat cultures of recombinant Aspergillus oryzae. Biotechnol Bioeng 62, 434-46.

Antošová M and Polakoviè M (2001) Fructosyltransferases: the enzymes catalyzing production of fructooligosaccharides. Chem Pap 55, 350-8.

Antošová M, Polakoviè M, Slovinská M, Madlová V, Illeová V, and Báleš V (2002) Effect of sucrose concentration and cultivation time on batch production of fructosyltransferase by Aureobasidium pullulans CCY 271-1194. Chem Pap 56, 394-9.

Ashokkumar B, Kayalvizhi N, and Gunasekaran P (2001) Optimization of media for beta-fructofuranosidase production by Aspergillus niger in submerged and solid state fermentation. Process Biochem 37, 331-8.
Balasubramaniem AK, Nagarajan KV, and Paramasamy G (2001) Optimization of media for $\beta$-fructofuranosidase production by Aspergillus niger in submerged and solid state fermentation. Process Biochem 36, 1241-7.

Bartholomew WH, Karrow EO, Sfat MR, and Wilhelm RH (1950) Oxygen transfer and agitation in submerged fermentations. Effect of air flow and agitation rates upon fermentation of Peni-cillium chrysogenum and Streptomyces griseus. Ind Eng Chem 42, 1801-9.

Chen WC (1995) Production of $\beta$-fructofuranosidase by Aspergillus japonicus in batch and fed-batch cultures. Biotechnol Lett 17, 1291-4.

Chen WC and Liu CH (1996) Production of $\beta$-fructofuranosidase by Aspergillus japonicus. Enzyme Microb Technol 18, 153-60.

Cruz R, Cruz VD, Belini MZ, Belote JG, and Vieira CR (1998) Production of fructooligosaccharides by the mycelia of Aspergillus japonicus immobilized in calcium alginate. Bioresour Technol 65, 139-43.

Cuervo R, Guilarte B, Juárez A, and Martýnnez J (2004) Production of fructooligosaccharides by $\beta$-fructofuranosidase from Aspergillus sp. $27 \mathrm{H}$. $J$ Chem Technol Biotechnol 79, 268-72.

De Meo M, Laget M, Phan-Tan-Luu R, Mathicu D, and Dumenil G (1985) Application of experimental designs for optimization of medium and culture conditions in fermentation. Biosci 4, 99-102.

Dhake AB and Patil MB (2007) Effect of substrate feeding on production of fructosyltransferase by Penicillium purpurogenum. Brazil J Microbiol 38, 194-9.

Dorta C, Cruz R, Neto PO, and Moura DJC (2006) Sugarcane molasses and yeast powder used in the fructooligosaccharides production by Aspergillus japonicas FCL 119Tand Aspergillus niger ATCC 20611. J Ind Microbiol Biotechnol 33, 1003-9.

Duan KJ, Sheu DC, and Chen JS (1993) Purification and characterization of $\beta$-fructofuranosidase from Aspergillus japonicus TIT-KJ1. Biosci Biotechnol Biochem 57, 1811-5.

Frost GM and Moss DA (1987) Production of enzymes by fermentation. In Biotechnol Kennedy, J. F. Ed., Elsevier Applied Science, London, UK. Vol, 7a, 134.

Hayashi S, Matsuzaki K, Takasaki Y, Ueno H, and Imada K (1992) Production of $\beta$-fructofuranosidase by Aspergillus japonicus. World $J$ Microbiol Biotechnol 8,155-9.

Hayashi S, Yoshiyama T, Fujii N, and Shirohara S (2000) Production of a novel syrup containing neo-fructooligosaccharides by the cells of Penicillium citrinum. Biotechnol Lett 22, 1465-9.

Lejeune R and Baron GV (1995) Effect of agitation on growth and enzyme production of Trichoderma ressei in batch fermentation. Appl Microbiol Biotechnol 43, 249-58.

Lim JS, Lee JH, Kim JM, Park SW, and Kim SW (2006) Effects of 
morphology and rheology on neo-fructosyltransferase production by Penicillium citrinum. Biotechnol Bioprocess Eng 11, 100-4.

Lowry OH, Reserbrough J, Fan AC, and Randall RI (1951) Protein measurement with Folin phenol reagent. J Biol Chem 193, 265.

Maiorano AE, Piccoli RM, da Silva ES, and Rodrigues MF (2008) Microbial production of fructosyltransferases for synthesis of pre-biotics. Biotechnol Lett 30, 1867-77.

Moubasher AH (1993) Soil fungi in Qatar and other Arab countries. MS Thesis, University of Qatar, Qatar.

Nascimento WCA and Martins MLL (2004) Production and properties of an extracellular protease from thermophilic Bacillus sp. Brazil J Microbiol 35 (1-2), 91-6.

Nguyen QD, Szabó JMR, Bhat MK, and Hoschke AP (2005) Purification and some properties of $\beta$-fructofuranosidase from Aspergillus niger IMI303386. Process Biochem 40, 2461-6.

Ottoni CA, Cuervo-Fernández R, Piccoli RM, Moreira R, Guilarte-Maresma B, Sabino da Silva E et al. (2012) Media optimization for $\beta$ fructofuranosidase production by Aspergillus oryzae. Brazil J Chem Eng 29, 49-59.

Parkinson D, Gray TRG, and Williams ST (1971) Methods for studying the ecology of soil microorganisms. International Biological Programme Handbook No 19. Blackwell, UK.

Samson RA, Hoekstra ES, Frisvad JC, and Filtenborg O (2000) Methods for the detection, isolation and characterization of food-borne fungi. In Introduction to food- and airborne fungi, RA Samson, ES Hoekstra, JC Frisvad, O Filtenborg (eds), Utrecht: Centraalbureau voor Schimmelcultures,
Nederland.

Sangeetha PT, Ramesh MN, and Prapulla SG (2004) Production of fructooligosaccharides by fructosyltransferase from Aspergillus oryzae CFR 202 and Aureobasidium pullulans CFR 77. Process Biochem 39, 753-8.

Sangeetha PT, Ramesh MN, and Prapulla SG (2005) Fructooligosaccharide production using fructosyl transferase obtained from recycling culture of Aspergillus oryzae CFR 202. Process Biochem 40, 1085-8.

Somogyi M (1945) Notes on sugar determination. J Biol Chem 160, 16-23.

Vandáková M, Platková M, Antošová M, Báles V, and Polakoviè M (2004) Optimization of cultivation conditions for production of fructosyltransferase by Aureobasidium pullulans. Chem Pap 58(1), 15-22.

Venkatadri R and Irvine R (1990) Effect of agitation on ligninase activity and ligninase production by Phanerochaete chrysosporium. Appl Environ Microbiol 56, 2684-91.

Wang LM and Zhou HM (2006) Isolation and identification of a novel Aspergillus japonicus JN19 producing $\beta$-fructofuranosidase and characterization of the enzyme. J Food Biochem 30, 641-58.

Wang XD and Rakshit SK (1999) Improved extracellular transferase enzyme production by Aspergillus foetidus for synthesis of isooligosaccharides. Bioprocess Eng 20, 429-34.

Yun JW (1996) Fructooligosaccharides, occurrence, preparation, and application. World J Microbiol Biotechnol 19, 107-17.

Yun JW, Kim DH, Moon HY, Song CH, and Song SK (1997) Simultaneous formation of fructosyltransferase and glucosyltransferase in Aureobasidium pullulans. J Microbiol Biotechnol 7, 204-8. 